\title{
Dorylaimoidea (Nematoda) from rivers in the Kruger National Park
}

\section{ANNELIZE BOTHA and J. HEYNS}

Botha, Annelize and J. Heyns. 1991. Dorylaimoidea (Nematoda) from rivers in the Kruger National Park. Koedoe 34(2): 1-24. Pretoria. ISSN 0075-6458.

\begin{abstract}
This paper deals with nematodes from rivers in the Kruger National Park. Three new species are described, viz. Dorylaimus deaconi n.sp., Laimydorus olifanti n.sp. and Aporcelaimellus glandus n.sp. Lenonchium fimbricaudatum Swart \& Heyns, 1991, Aporcelaimellus micropunctatus Botha \& Heyns, 1990, Discolaimus monoplanus Heyns, 1963, Discolaimus major Thorne, 1939 and Xiphinema italiae Meyl, 1953 have been recorded from the park before. Biometric data of the new populations are tabulated, and where appropriate illustrations are also given.
\end{abstract}

Keywords: Dorylaimoidea, Dorylaimus, Laimydorus, Aporcelaimellus, Lenonchium, Discolaimus, Xiphinema, Nematoda, taxonomy, Kruger National Park.

Annelize Botha and J. Heyns, Department of Zoology, Rand Afrikaans University, P.O. Box 524, Johannesburg, 2000 Republic of South Africa

\section{Introduction}

In previous papers we reported on various Dorylaimoidea (Botha \& Heyns 1990b) and Aporcelaimidae (Botha \& Heyns 1990a) which were obtained from soil samples taken at several localities in the Kruger National Park. The present paper deals with nematode species which were obtained from the sediment in several rivers in the park. Although three aquatic nematode species were found, several species, which are normally found in terrestrial habitats, were also collected from these rivers. This is not unusual, since terrestrial nematodes are commonly found in rivers and other freshwater bodies, after being washed into streams and rivers with excess irrigation water, or perhaps more commonly, after torrential rains.

\section{Materials and Methods}

Specimens were killed by gentle heat, fixed in FAA and processed into glycerine by Thorne's slow method and mounted on permanent slides. Measurements and drawings were done with the aid of a Zeiss Standard 18 research microscope, equipped with a drawing tube. Light microscope photographs were taken with a MC 63 photomicrographic camera and differential interference contrast. All measurements, except the total body length which is in $\mathrm{mm}$, are given in $\mu \mathrm{m}$ in the tables as well as in the text. Curved structures, e.g. spicules, were measured along the curved median line.
For scanning electron microscope studies, specimens mounted in glycerine were slowly hydrated in distilled water, post-fixed in $1 \%$ Osmium Tetroxide $\left(\mathrm{O}_{\mathrm{s}} \mathrm{O}_{4}\right)$, dehydrated in an ethanol distilled water series, put in the critical point dryer, mounted on aluminium SEM-studs, sputter-coated with gold and viewed with an ISI ss60 SEM at $6 \mathrm{kV}$.

All specimens, except where otherwise stated, are deposited in the collection of the Department of Zoology, Rand Afrikaans University.

\section{Descriptions}

Family: Dorylaimidae De Man, 1876

Dorylaimus deaconi n.sp. (Figs. 1A-I; 2A-F and $3 \mathrm{~A}-\mathrm{E}$ )

Morphometric data in Table 1.

Female

Relatively large nematode, with slender body. Heat-relaxed body posture almost straight (Fig. 1I). Cuticle relatively thick: 4-5 $\mu \mathrm{m}$ on the neck; 4-7,5 $\mu \mathrm{m}$ at mid-body; and $5,5-7,5 \mu \mathrm{m}$ on dorsal side of tail. Cuticle with distinct transverse striae. Longitudinal body ridges 33 (Figs. 2B, 3E), regularly spaced, 5 $\mu \mathrm{m}$ apart; very prominent at mid-body, but decreasing to faint lines on neck (Fig. 2A) and tail (Fig. 2C). Lateral chord one fourth body diameter at base of oesophagus, granular and with small cells. Dorsal and ventral body 
pores distinct. Dorsal body pores 6 , limited to oesophageal region. Ventral body pores 16 23 , distributed over entire body (11-14 to base of oesophagus, 2-5 between oesophagus and vulva, and 3-4 between vulva and anus). Lateral body pores obscure.

Lip region slightly narrower than adjoining body, slightly set off (Figs. 1A\&B, 3A). Lips amalgamated, rather angular in outline. Amphid stirrup-shaped (Fig. 1B), the aperture slightly less to slightly more than half the lip region width. Odontostyle very distinct, its length about twice lip region width. Aperture of odontostyle relatively small, about one third of stylet length. Stylet width about one eighth stylet length. Odontophore distinct, rod-like, not expanded at its base, about twice as long as lip region width. Guiding ring double. Hemizonid situated anterior to or opposite nerve ring. One pair of endolids situated anterior to nerye ring. Anterior part of oesophagus which surrounds odontophore not expanded and apparently not muscular. Cardia large, conoid; basal two thirds enveloped by tissue of intestinal cells. Position of oesophageal gland nuclei and their openings as follows $(n=1)$ : $\mathrm{DO}=51,8 ; \quad \mathrm{DN}=53,4$; $\mathrm{S}_{1} 0_{2}=75,9 ; \mathrm{S}_{1} \mathrm{~N}_{2}=76 ; \mathrm{S}_{2} 0_{1}=89,7 ; \mathrm{S}_{2} \mathrm{O}_{2}=90$; $\mathrm{S}_{2} \mathrm{~N}_{2}=88,6 ; \mathrm{S}_{1} 0_{1}, \mathrm{~S}_{1} \mathrm{~N}_{1}$ and $\mathrm{S}_{2} \mathrm{~N}_{1}$ obscure.

Intestine about 6 cells in circumference; cells large and packed with brownish granules. Junction between intestine and prerectum distinct. Very distinct sphincter at junction of prerectum and rectum. Prerectum length 4,37,7 times anal body diameter. Rectum 1,3-1,8 times anal body diameter. Tail elongate-conoid with subacute terminus (Fig. 1G). Three pairs of caudal pores present; one pair subdorsally, one pair laterally and one pair subventrally.

Female didelphic, amphidelphic (Fig. 1E\&F). Ovaries reflexed. Pars dilatata oviductus and pars dilatata uteri separated by a sphincter muscle. Pars dilatata oviductus very large and distinct, packed with sperm cells. Pars dilatata uteri small, only slightly expanded, without sperm cells; rest of uterus packed with sperm cells. Ovejector not clearly differentiated. Vagina strongly mus- cular, reaching $38-45,7 \%$ of the corresponding body diameter. Vulva a small longitudinal slit, 5,5 $\mu \mathrm{m}$ in length. Uterus 4-19 eggs, measuring 56-80 x 28-37 $\mu \mathrm{m}(n=48)$.

Male.

Male similar to female except posterior part of body more strongly ventrally curved, in the shape of the letter J (Fig. 1I). Male diorchic, testes opposed and outstretched. Anterior testis reaching to the base of the oesophagus. Testes obscured by dense granules of intestinal cells.. Spicules (Fig. 3D) relatively slender, 71-86 $\mu \mathrm{m}$ long; lateral guiding pieces $12-17 \mu \mathrm{m}$ long. In addition to an adanal pair, a series of 35-42 contiguous ventromedian supplements present (Fig. 2E). The anteriormost as well as the posteriormost ten ventromedian supplements of the series are elevated above the body contour, in contrast to the central ones which are flush with the outline of the body (Fig. 3C). The adanal and ventromedian supplements are situated on a distinct midventral ridge bordered by subventral grooves. Subventral papillae 25-34 pairs, spaced irregularly up to prerectum intestine junction. Copulatory muscles numerous, extending beyond the supplement region. Tail short, convex-conoid and bluntly rounded (Figs. 1H; 2D\&E and 3D). Six pairs of caudal pores present; four pairs situated near the terminus of the tail, one pair subdorsal and one pair subventral. Prerectum length 8-15 times anal body diameter.

\section{Diagnosis}

Dorylaimus deaconi $\mathrm{n} . \mathrm{sp}$. is a relatively large nematode with distinct longitudinal body ridges; a distinct and slender odontostyle; a rod-like odontophore without a swollen base; an elongate-conoid female tail with a subacute terminus and a short, convex-conoid male tail which is bluntly rounded. The vulva is a small longitudinal slit.

\section{Differential diagnosis}

Dorylaimus deaconi n.sp. is close to $D$. afghanicus Andrássy, 1960, D. helveticus Steiner, 1919 and D. lineatus Altherr \& 
Delamare-Deboutteville, 1972. It can be distinguished from $D$. afghanicus by a relatively shorter oesophagus $(b=4,5-6,4$ compared with $b=4,3-5,1)$; a slightly shorter odontostyle (39-48,5 $\mu \mathrm{m}$ compared with $46-50 \mu \mathrm{m})$; and smaller eggs (56-80 x 28-37 $\mu \mathrm{m}$ compared with 84-104 x 41-49 $\mu \mathrm{m})$. The male of D. deaconi n.sp. has shorter spicules (71-86 $\mu \mathrm{m}$ compared with $100 \mu \mathrm{m})$; less ventromedian supplements (35-42 compared with 52) and a relatively shorter tail (c=87,5 - 140,0 compared with $\mathrm{c}=74,3)$. D. deaconi $\mathrm{n}$.sp. can be distinguished from $D$. lineatus by less longitudinal body ridges(33 body ridges compared with $40-50$ body ridges); a more anteriorly situated vulva (V=34,7-42\% compared with $\mathrm{V}=45-51 \%$ ); the rectum of the female is relatively longer (rectum length 1,3-1,8 times anal body diameter compared with rectum length 1,0-1,5 times anal body diameter); prerectum of female relatively longer (prerectum length 4,3-7,7 times anal body diameter compared with prerectum length 3,0-4,0 times anal body diameter); the male has a relatively shorter oesophagus ( $b=4,6-6,0$ compared with $b=3,8-4,1) ; a$ slightly thicker cuticle (4-7,5 $\mu \mathrm{m}$ compared with 3-5 $\mu \mathrm{m})$; and slightly shorter lateral guiding pieces $(12-17 \mu \mathrm{m}$ compared with $16-18 \mu \mathrm{m})$.

Steiner (1919) described his specimens from the Neuenburger Lake as a subspecies of Dorylaimus fecundus Cobb, 1914. Thorne \& Swanger (1936) described specimens from Switzerland, Russia, Canada and the USA, which agreed with the description of $D$. fecundus Cobb, 1914, subsp. helveticus Steiner, 1919, but because of the distinct longitudinal body ridges they regarded it as a distinct species and thus they elevated Steiner's sub- species to species rank as $D$. helveticus.

Although $D$. deaconi n.sp. is close to $D$. helveticus as conceived by Thorne \& Swanger (1936) it can be distinguished from this species by a more slender body $(a=34,5-46$ compared with $\mathrm{a}=28$ ); a more anteriorly situated vulva $(\mathrm{V}=34,7-42 \%$ compared with $\mathrm{V}=46 \%)$; shorter spicules $(71-86 \mu \mathrm{m}$ compared with $100 \mu \mathrm{m})$; relatively longer female tail $(\mathrm{c}=11,2-15,4$ compared with $\mathrm{c}=24)$ and a relatively shorter male tail $(c=87,5-140,0$ compared with $\mathrm{c}=67$ ).

\section{Type locality and habitat}

Holotype and 19 paratypes from four different localities in the Sabie River namely: in the sand of a stagnant pool and from the river bank between the Nkuhlu picnic area and Lower Sabie Camp; in the sand between Phragmites at the weir east of Lower Sabie Camp and in wet sand east of the Skukuza Camp, collected by A. Botha and J. Heyns in February, 1990. Six paratypes from two different localities in the Olifants River namely: in the sediment at the weir west of the Olifants Camp and in sediment just east of the weir, collected by J. van Vuren in June, 1990. Twenty nine paratypes from four different localities in the Luvuvhu River namely: in a stagnant shallow pool west of Pafuri; in the river east of the old Pafuri picnic area; in a stagnant pool east of Pafuri and from the river bank at the junction of the Luvuvhu and Limpopo rivers, collected by J. Heyns in February, 1991.

\section{Type specimens}

Holotype from Sabie River on slide W2529, paratypes from Sabie River on slides W2522, W2524, W2525, W2527, W2529, W2536, W2560, W2566, W2569, W2570, W2602 and W2647; paratypes from Olifants River on slides W2674-2676 and W2679; paratypes from Luvuvhu River on slides W2844-W2847, W2852, W2856, W2860W2863, W2865, W2884 and W2877.

Laimydorus olifanti n.sp. (Figs. 4A-K and $5 \mathrm{~A}-\mathrm{C})$

Morphometric data in Table 2.

Female

Relatively large nematode, with slender body. Heat-relaxed body posture almost straight; terminal part of tail sometimes dorsally curved (Fig. 4K). Cuticle relatively thick: $3-3,5 \mu \mathrm{m}$ on the neck; $3-4 \mu \mathrm{m}$ at mid- 


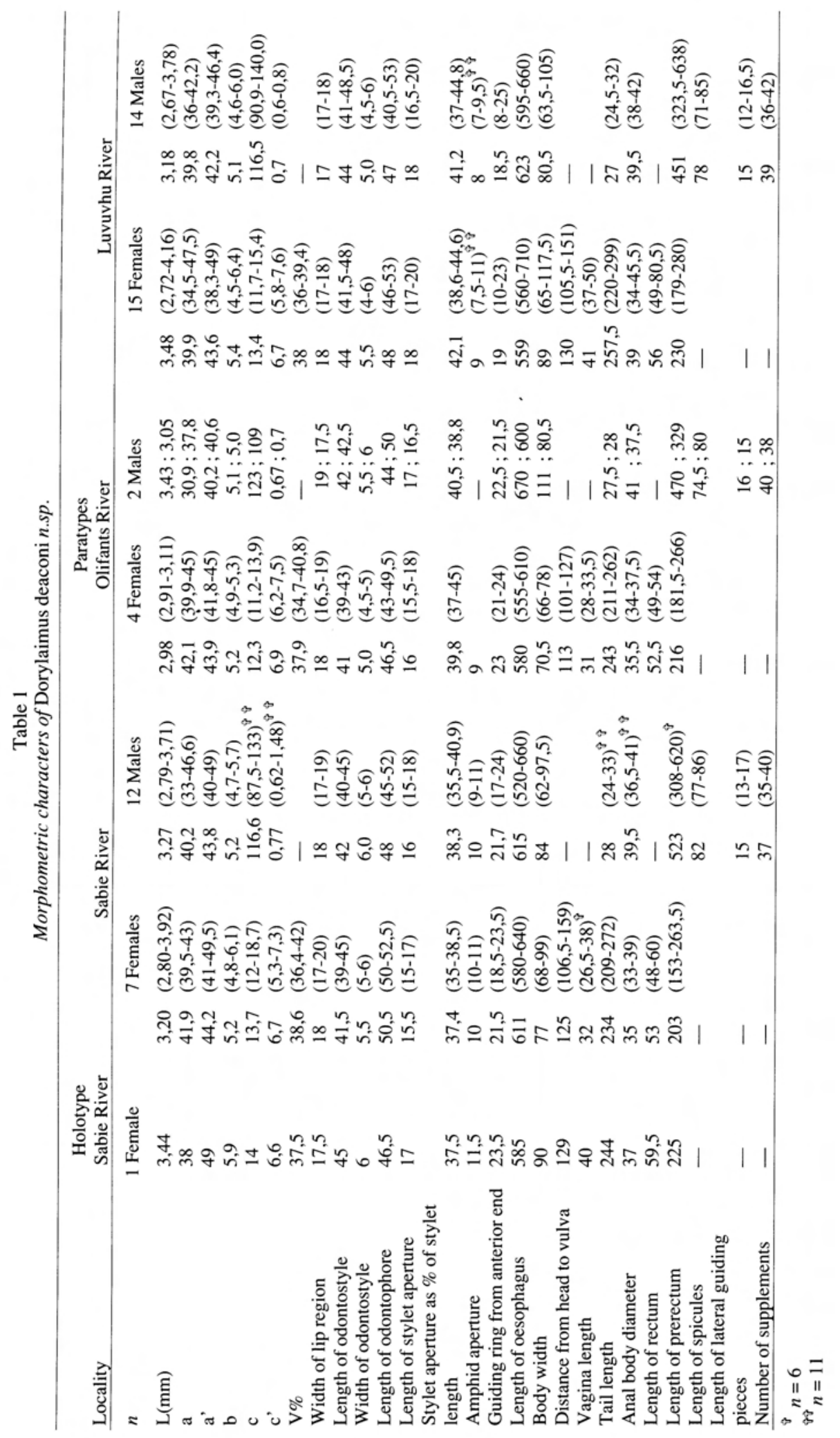




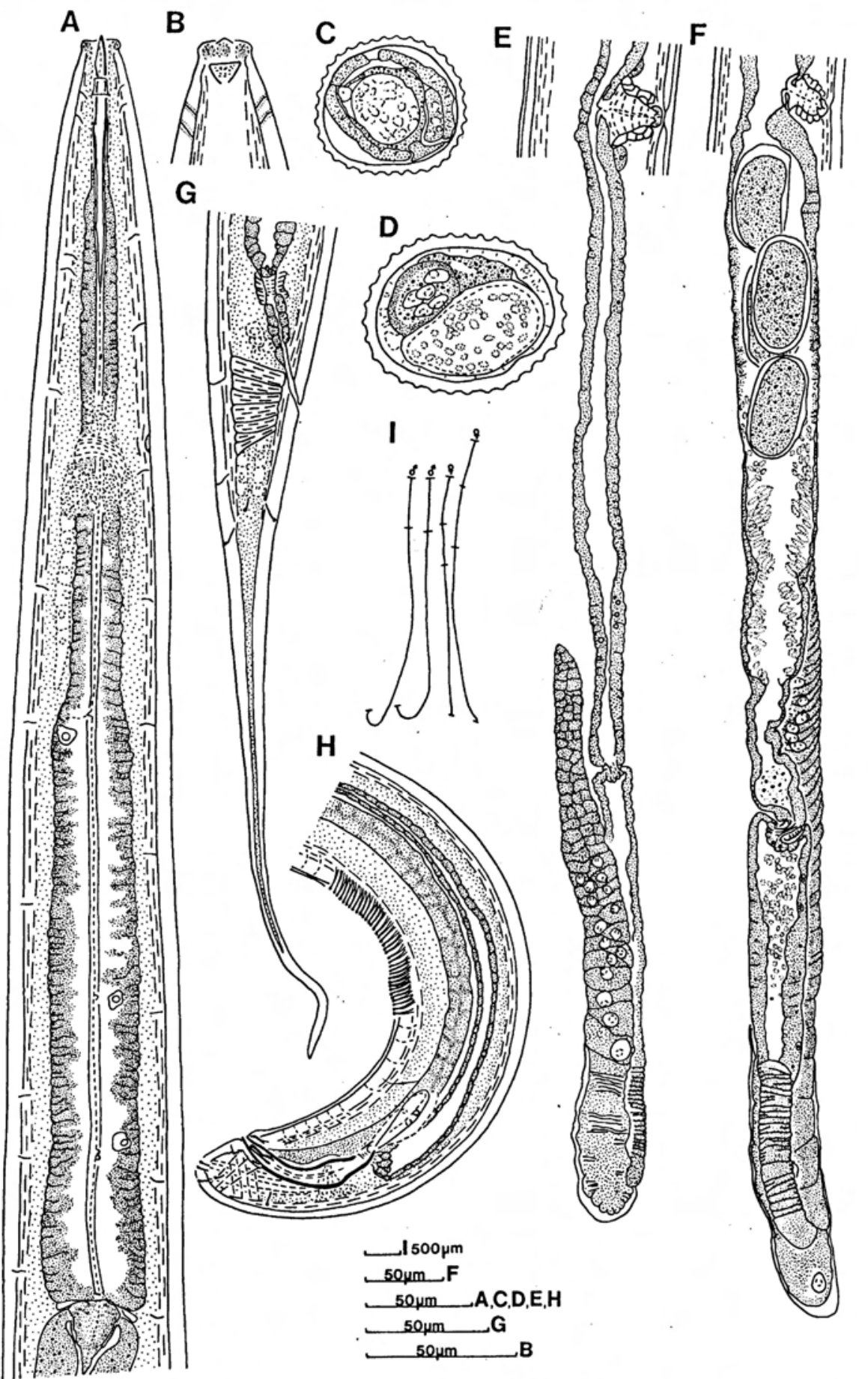

Fig. 1. Dorylaimus deaconi n.sp.: A. Anterior body region of female; B. Shape and position of amphid; C. Cross-section through mid-body (male); D. Cross-section through mid-body (female); E and F. Posterior branch of reproductive system of female; G. Female tail; H. Male tail; I. Heat-relaxed body posture of two males and two females. 


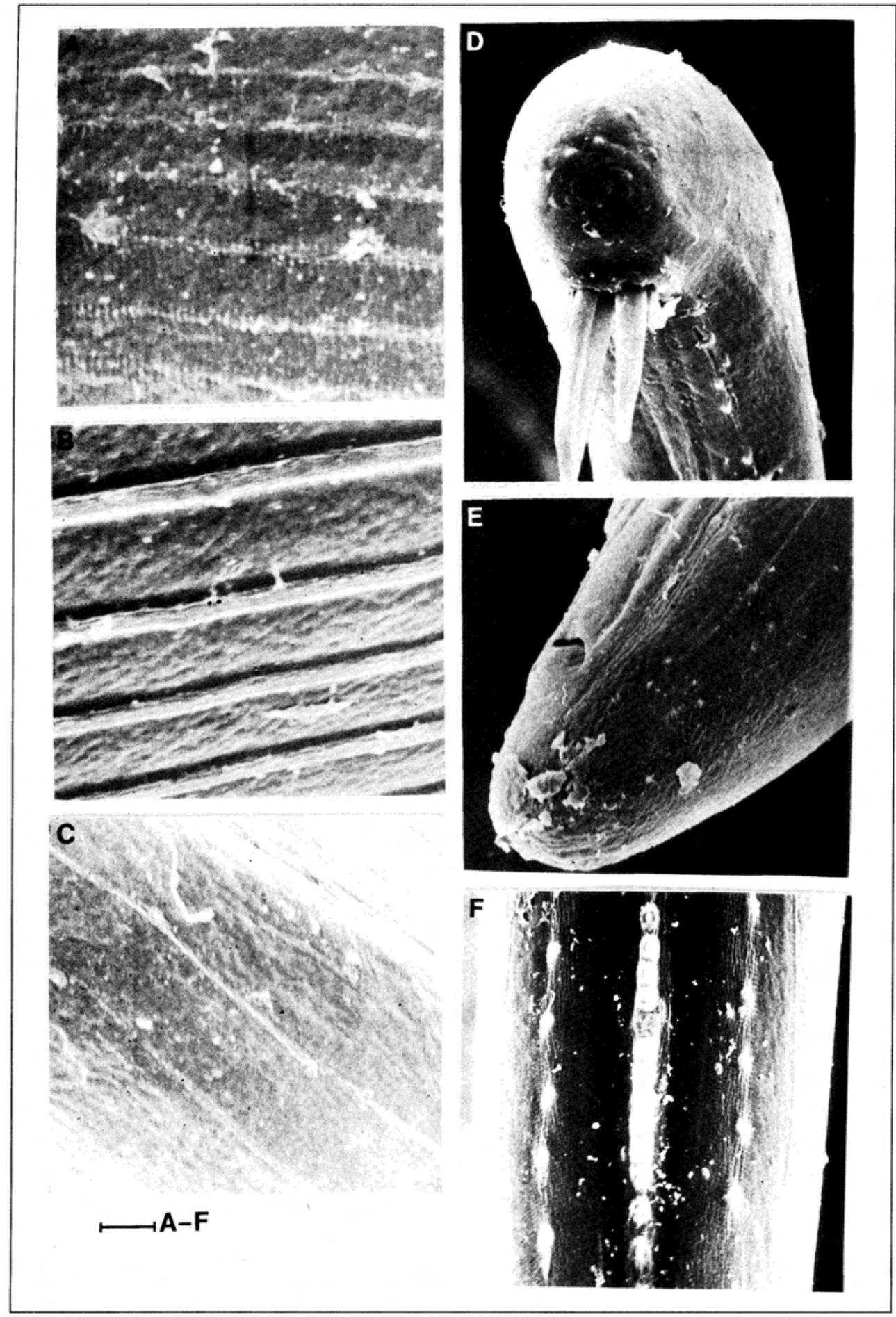

Fig. 2. Dorylaimus deaconi n.sp.: A. Cuticle in neck region (bar equals $4 \mu \mathrm{m}$ ); B. Cuticle at mid-body (bar equals $4 \mu \mathrm{m}$ ); C. Cuticle in tail region (bar equals $3 \mu \mathrm{m}$ ); D. En face view of male tail region (bar equals 9 $\mu \mathrm{m}$ ); E. Posterior region of male tail (bar equals $6 \mu \mathrm{m}$ ); F. Ventro- median supplements of male (bar equals $4 \mathrm{~mm})$. 


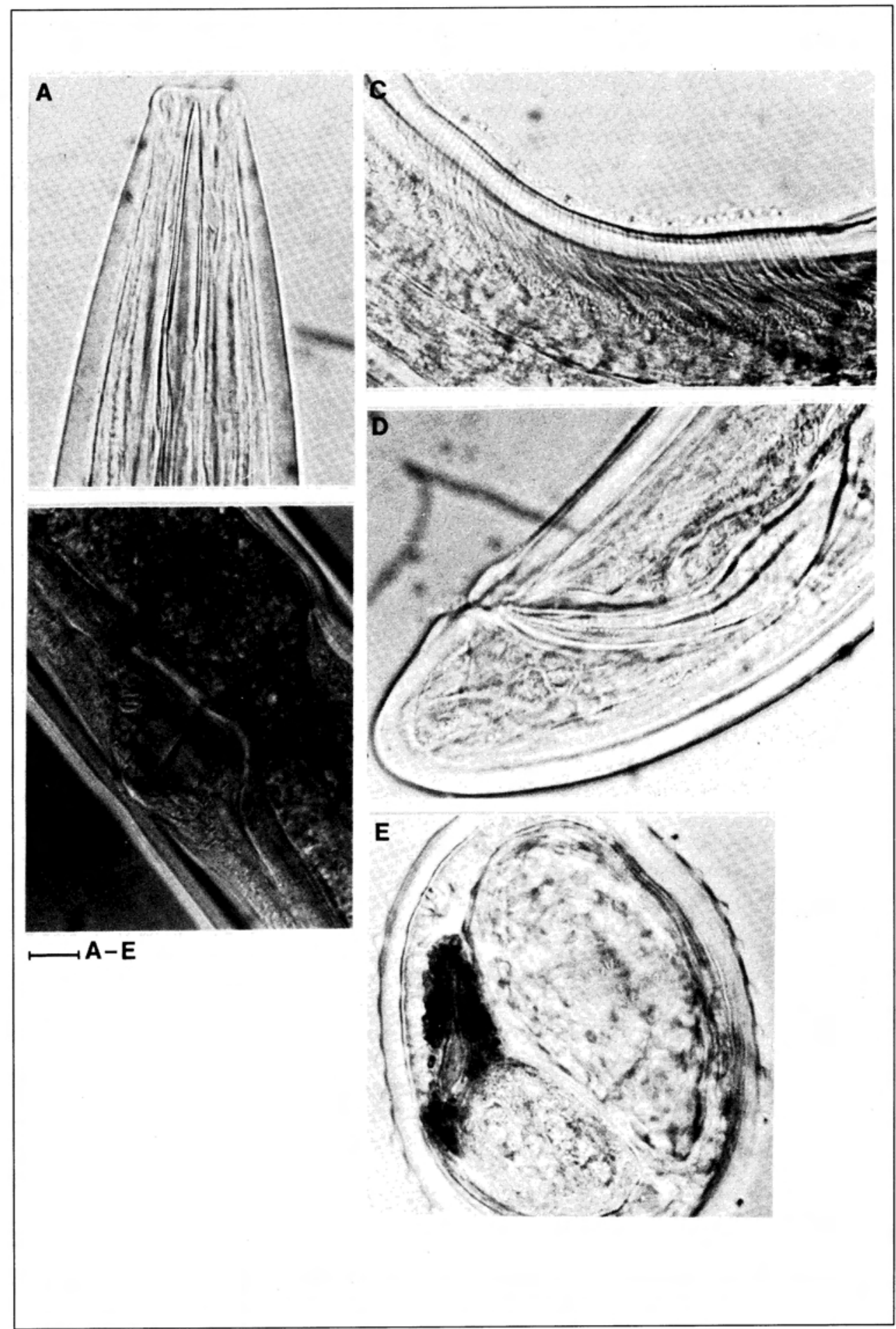

Fig. 3. Dorylaimus deaconi n.sp. A. Lateral view of head (bar equals $9,5 \mu \mathrm{m}$ ); B. Vaginal region (bar equals $10 \mu \mathrm{m}$ ); C. Ventromedian supplements of male (bar equals $11 \mu \mathrm{m}$ ); D. Posterior region of male tail (bar equals $10 \mu \mathrm{m})$; E. Cross-section through mid-body (female) (bar equals $11 \mu \mathrm{m}$ ). 
body; and 4,5-5,5 $\mu \mathrm{m}$ on dorsal side of tail. Cuticle with relatively distinct transverse striae. Lateral chord one fourth to one third body diameter at base of oesophagus, appearing granular. Dorsal and ventral body pores obscure; lateral body pores distinct, but since all specimens are spirally twisted, the number of lateral body pores could not be determined.

Lip region weakly set off, about one fourth as wide as body at base of oesophagus. Lips amalgamated and rounded (Fig. 4A\&C). Amphid stirrup- shaped (Fig. 4B), aperture equal to or slightly less than half of lip region width. Amphid when viewed laterally, appearing to be divided into two parts. Odontostyle distinct and relatively slender, its length about twice the lip region width. Aperture of odontostyle relatively small, slightly more than one third stylet length. Stylet width about one eighth stylet length. Odontophore relatively distinct, rod-like, not expanded at its base and about twice as long as lip region width. Guiding ring double. Hemizonid situated opposite nerve ring. Anterior part of oesophagus, which surrounds odontophore, slightly expanded. One pair of endolids situated anterior to nerve ring. Nerve ring situated at $127-137 \mu \mathrm{m}$ from anterior end. Cardia large, conoid, about as long as or slightly longer than width of basal bulb of oesophagus; 5-7 "coelomocyte-like" structures situated in the region of the oesophagus base (Fig. 5A-C). Position of oesophageal gland nuclei and their openings as follows $(n=3): \mathrm{DO}=54,9(54,2-56)$; $\mathrm{DN}=55,6(54,8-56,1): \mathrm{S}_{10}=72,5(71,273,9)$; $\mathrm{S}_{1} \mathrm{~N}_{1}=72,8(72,2-73,9) ; \quad \mathrm{S}_{1} 0_{2}=77,5(76,7-$ $78,3) ; \quad \mathrm{S}_{1} \mathrm{~N}_{2}=78,3(76,7-79,2) ; \quad \mathrm{S}_{2} 0_{1}=89,3$ $(89,1-89,6) ; \quad \mathrm{S}_{2} \mathrm{~N}_{1}=88,1 \quad(88,0-88,3)$; $\mathrm{S}_{2} \mathrm{O}_{2}=89,5(89,3-89,9) ; \quad \mathrm{S}_{2} \mathrm{~N}_{2}=88,4(88,2-$ 88,8 ).

Intestinal cells somewhat obscure due to the great number of brownish granules. Junction between intestine and prerectum distinct. Sphincter at junction of prerectum and rectum obscure. Prerectum length 4,0-6,3 times anal body diameter. Rectum 1,1-1,3 times anal body diameter. Tail long, almost filiform, with an acute terminus (Fig. $4 \mathrm{H}$ ). One pair of subyentral and two pairs of subdorsal caudal pores present.

Female didelphic, amphidelphic (Fig. 4I-J). Reproductive system very clearly differentiated. Ovaries reflexed dorsally. Pars dilatata oviductus and pars dilatata uteri relatively distinct; separated by a very distinct sphincter muscle. Pars dilatata oviductus relatively long, with sperm cells. Oviduct short and broad, with approximately 14 distinct cells. Uterus divided into three parts: first part packed with sperm cells; second part relatively short and cellular; and a third tuboid part which expands slightly to form the pars dilatata uteri. Last two parts without sperm cells. Ovejector not clearly differentiated. Vagina muscular (Fig. 4E) reaching 47$53,1 \%$ of the corresponding body diameter. Vulva a small longitudinal slit (Fig.4D) without sclerotized labia. Uterus with 1-2 eggs, measuring 79-84,5 x 28,5-32,5 $\mu \mathrm{m}(n=4)$.

\section{Male}

Male similar to female except posterior part of body slightly more ventrally curved (Fig. $4 \mathrm{~K}$ ). Male diorchic, testes opposed and outstretched. Testes obscured by dense granules of intestinal cells. Sperm cells spindle-shaped (Fig. 4F), 11,5-12,5 $\mu \mathrm{m}$ long. Spicules relatively robust, $39,5-50 \mu \mathrm{m}$ long. Lateral guiding pieces absent. Supplements consisting of an adanal pair and 19-23 ventromedians. The ventromedian supplements are arranged in the following manner: first a group of 9-11 contiguous ones, then 3-5 more widely spaced and finally again 5-9 more or less contiguous supplements. Subventral papillae 14-17 pairs, irregularly spaced, reaching to prerectum-intestine junction. Copulatory muscles also extending up to prerectum-intestine junction. Tail dorsally convex, ventrally slightly concave, bluntly rounded (Fig. 4G). Six pairs of caudal body pores present, two pairs situated near the terminus of the tail, one pair situated subventrally and three pairs sublaterally. Prerectum length 8-14 times anal body diameter. 
Table 2

Morphometric characters of Laimydorus olifanti $n . s p$.

\begin{tabular}{llllll}
\hline Locality & \multicolumn{5}{c}{ Olifants River } \\
\hline & Holotype & \multicolumn{4}{c}{ Paratypes } \\
\hline$n$ & 1 Female & & 3 Females & & 4 Males \\
L(mm) & 2,38 & 2,45 & $(2,37 ; 2,40 ; 2,59)$ & 1,96 & $(1,91-2,10)$ \\
a & 46,7 & 43,3 & $(42,3 ; 41,4 ; 46,3)$ & 38,6 & $(37,1-40,8)$ \\
b & 5,5 & 5,5 & $(5,3 ; 5,3 ; 6,0)$ & 4,6 & $(4,1-5,3)$ \\
c & 6,7 & 6,5 & $(6,5 ; 6,5 ; 6,4)$ & 132,9 & $(117,6-144,8)$ \\
c' & 13,2 & 14,2 & $(13,7 ; 14,4 ; 14,5)$ & 0,6 & $(0,58-0,61)$ \\
V\% & 42,0 & 43,5 & $(44,7 ; 45,0 ; 40,9)$ & - & \\
Width of lip region & 12 & 13 & $(12 ; 13,5 ; 13)$ & 13 & $(12,5-13)$ \\
Length of odontostyle & 24 & 24 & $(25 ; 25 ; 23)$ & 24,5 & $(24-25)$ \\
Width of odontostyle & 3,5 & 3 & $(3 ; 3,5 ; 3,5)$ & 3,4 & $(3-3,5)$ \\
Length of odontophore & 27,5 & 30 & $(30 ; 28,5 ; 31)$ & 28 & $(26,5-29,5)$ \\
Length of stylet aperture & 9,5 & 9 & $(9 ; 10 ; 9)$ & 10 & $(9-10)$ \\
Stylet aperture as \% of stylet length & 39,6 & 38,3 & $(36 ; 40 ; 39)$ & 39,3 & $(36,7-40,8)$ \\
Amphid aperture & 6 & 6 & & 6 & \\
Guiding ring from anterior end & 10,5 & 11 & $(13 ; 11 ; 8,5)$ & 11 & $(10-11,5)$ \\
Length of oesophagus & 430 & 443 & $(450 ; 450 ; 430)$ & 431 & $(400-465)$ \\
Body width & 51 & 57 & $(56 ; 58 ; 56)$ & 51,5 & $(51-52)$ \\
Distance from head to vulva & 101 & 107 & $(106 ; 108 ; 106)$ & - & \\
Vagina length & 24 & & $(-; 25 ; 24)$ & - & \\
Tail length & 357 & 379 & $(364 ; 367 ; 406)$ & 15 & $(14-16,5)$ \\
Anal body diameter & 27 & 27 & $(26,5 ; 25,5 ; 28)$ & 25 & $(24-27)$ \\
Length of rectum & 33 & 31 & $(28 ; 30 ; 35)$ & - & \\
Length of prerectum & 108,5 & 129 & $(160 ; 110,5 ; 116)$ & 300 & $(226-343,5)$ \\
Length of spicules & - & - & & 46 & $(39,5-50)$ \\
Number of supplements & - & - & & 22 & $(19-23)$ \\
\hline \% & & & & &
\end{tabular}

${ }^{8} n=2$

\section{Diagnosis}

Laimydorus olifanti $\mathrm{n} . \mathrm{sp}$. is a relatively large nematode with a distinct and slender odontostyle; a distinct rod-like odontophore without a swollen base and 'coelomocytelike' structures situated in the region of the oesophagus base. Female tail long, almost filiform with an acute terminus and a short dorsally convex, ventrally slightly concave male tail which is bluntly rounded. Vulva a small longitudinal slit without sclerotized labia.

\section{Differential diagnosis}

Laimydorus olifanti n.sp. is close to Laimydorus cryptosperma Loof, 1969 and Laimydorus gazella Andrássy, 1970. It can be distinguished from L. cryptosperma by a relatively more slender body $(a=41,4-46,7$ compared with $\mathrm{a}=28-38$ ); a relatively shorter oesophagus $(b=5,3-6,0$ compared with $b=4,2-5,1)$; a relatively longer female tail
( $c=6,4-6,7$ compared with $c=10-12$ ); a relatively shorter male tail ( $c=117,6-144,8$ compared with $c=64-84)$; a slightly more anteriorly situated vulva ( $\mathrm{V}=40,9-45 \%$ compared with $\mathrm{V}=45-48 \%$ ); lip region weakly set off compared with lip region more strongly off set; a slightly longer odontostyle (23-25 $\mu \mathrm{m}$ compared with 20-22 $\mu \mathrm{m}$ ); shorter odontophore (26,5-31 $\mu \mathrm{m}$ compared with 33-35 $\mu \mathrm{m})$; shorter spicules (39,5-50 $\mu \mathrm{m}$ compared with $52-58 \mu \mathrm{m}$ ); and a different arrangement of the ventromedian supplements (all supplements contiguous in $L$. cryptosperma). L. olifanti $\mathrm{n}$.sp. can be distinguished from $L$. gazella by a relatively more slender female body $(a=41,4-46,7$ compared with $a=38-41$ ); a relatively shorter oesophagus $(b=5,3-6,0$ compared with $b=4,7-4,9)$; $a$ more anteriorly situated vulva ( $\mathrm{V}=40-45 \%$ compared with $\mathrm{V}=48-49 \%$ ); a relatively shorter male tail ( $\mathrm{c}=117,6-144,8$ compared with $\mathrm{c}=102)$; shorter spicules $(39,5-50 \mu \mathrm{m}$ compared with $58 \mu \mathrm{m}$ ); less supplements (19-23 compared with 28$)$; a smaller odonto- 


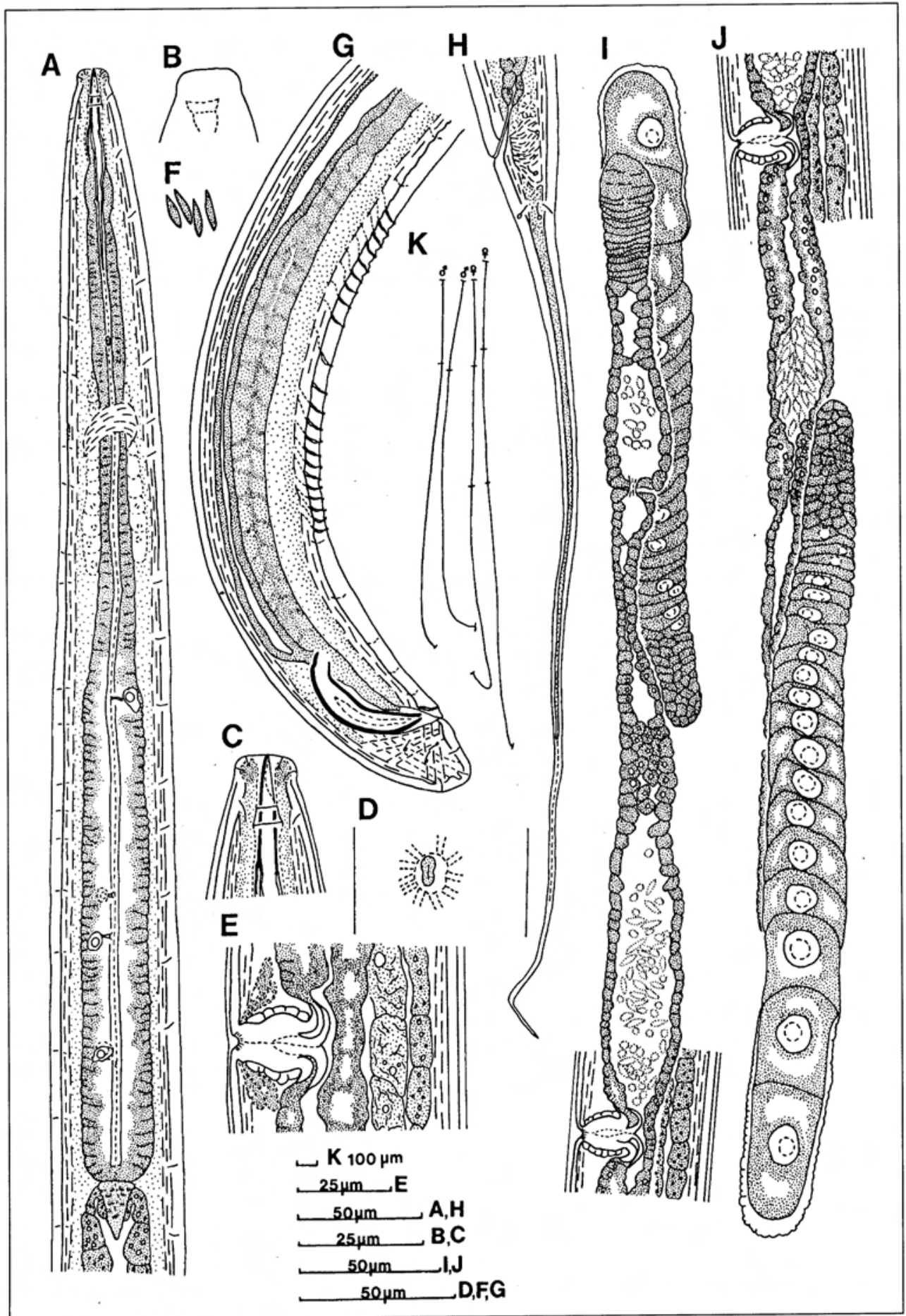

Fig. 4. Laimydorus olifanti n.sp.: A. Anterior body region of female; B. Shape and position of amphid; C. Lateral view of head; D. Dorso- ventral view of vulva; E. Vaginal region; F. Sperm cells of male; G. Posterior region of male; H. Female tail; I. Anterior branch of reproductive system of female; J. Posterior branch of reproductive system of female; K. Heat-relaxed body posture of two males and two females. 

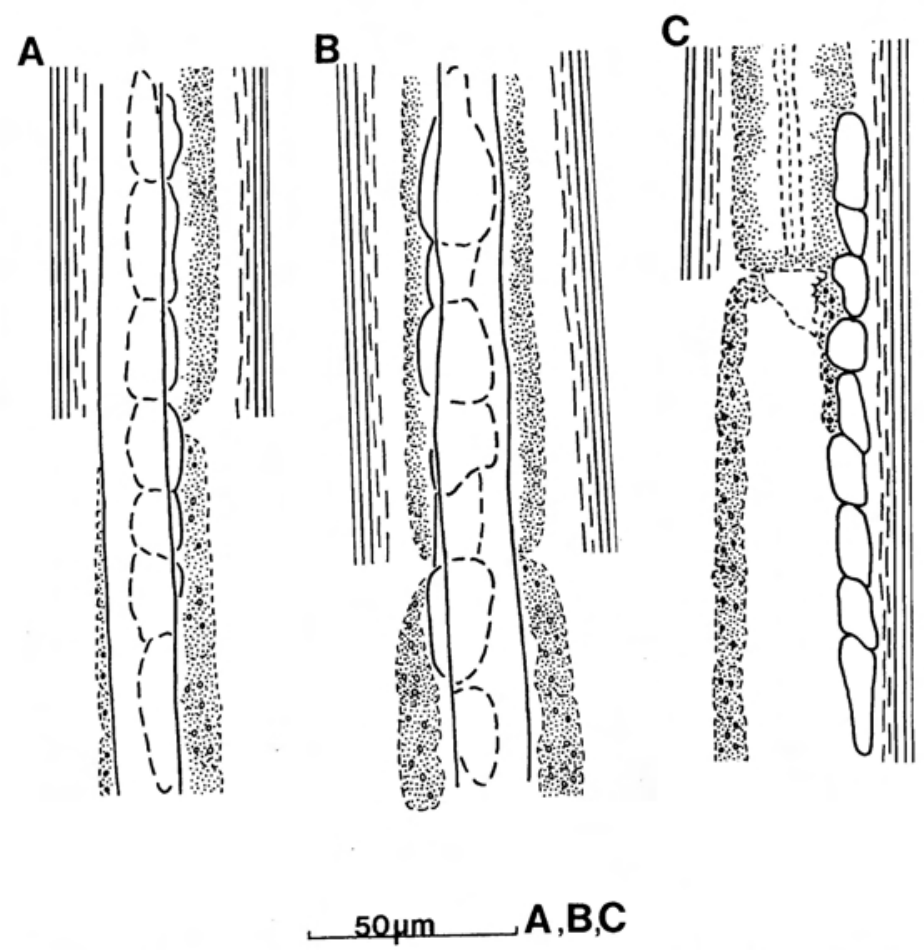

Fig. 5.Laimydorusolifanti n.sp.: A-C. "Coelomocyte-like" structures at base of oesophagus, showing variation in three specimens.

style (23-25 $\mu \mathrm{m}$ compared with $28-29 \mu \mathrm{m})$; narrower lip region $(12-13,5 \mu \mathrm{m}$ compared with $15-16 \mu \mathrm{m}$ ); labia of vulva unsclerotized compared with weakly sclerotized; and ventromedian supplements arranged in three groups compared with a contiguous series of supplements. Males of L. olifanti n.sp. are only 1,91-2,10 mm long, compared with 2,7 $\mathrm{mm}$ in L. gazella.

Type locality and habitat

Holotype and seven paratypes from sand in the Olifants River, west of the junction between the Letaba and Olifants rivers, collected by J. van Vuren in June, 1990.

Type specimens

Holotype on slide W2740 and paratypes on slides W2740, W2742, W2748, W2751, W2755, and W2757.
Family: Nordiidae Jairajpuri \& Siddiqi, 1964

Lenonchium fimbricaudatum Swart \& Heyns 1991

Morphometric data in Table 3.

The description of Lenonchium fimbricaudatum was based on specimens from wet soil, on the banks of the Sabie River in the Kruger National Park (Swart \& Heyns 1991). The present specimens of $L$. fimbricaudatum collected from sediment at the confluence of the Mbyamiti and Crocodile rivers, are in perfect agreement with the type population, except for a slightly shorter odontostyle (27,5-29,5 $\mu \mathrm{m}$ compared with 29-34 $\mu \mathrm{m})$ and a slightly smaller cardia (cardia length 16-19 um compared with $21 \mu \mathrm{m}$; cardia width 10$15 \mu \mathrm{m}$ compared with $15 \mu \mathrm{m})$. 
Table 3

Morphometric characters of Lenonchium fimbricaudatum Swart \& Heyns, 1991

\begin{tabular}{|c|c|c|c|}
\hline & Holotype & Specimens & Crocodile River \\
\hline$n$ & & & 3 Males \\
\hline $\begin{array}{l}n \\
\mathrm{~L}(\mathrm{~mm})\end{array}$ & $\begin{array}{l}1 \text { Female } \\
6.20\end{array}$ & $5,39: 5,86: 6,32$ & $\begin{array}{c}\text { 3 Males } \\
5,44 ; 5,68 ; 5,85\end{array}$ \\
\hline $\begin{array}{l}\mathrm{L}(\mathrm{mm}) \\
\mathrm{a}\end{array}$ & $\begin{array}{l}0,20 \\
103,4\end{array}$ & 89,$1 ; 103,7 ; 101,1$ & $\begin{array}{l}5,44 ; 5,68 ; 5,85 \\
98,9 ; 99,6 ; 97,5\end{array}$ \\
\hline b & 11,8 & 10,$6 ; 10,4 ; 12,0$ & $\begin{array}{l}98,9 ; 99,6 ; 91,5 \\
10,6 ; 10,4 ; 10,4\end{array}$ \\
\hline c & 28,0 & 33,$0 ; 25,3 ; 28,7$ & 31,$2 ; 35,1 ; 36,5$ \\
\hline c' & 5,6 & 4,$4 ; 6,3 ; 5,9$ & 4,$5 ; 3,8 ; 3,7$ \\
\hline $\mathrm{V} \%$ & 48,4 & $48 ; 46,6 ; 46,1$ & $-;-;-$ \\
\hline Width of lip region & 14 & $14 ; 14,5 ; 14$ & 14,$5 ; 13,5 ; 14$ \\
\hline Height of lip region & 6 & $7 ; 5,5 ; 6,5$ & 6,$5 ; 6 ; 6,5$ \\
\hline Length of odontostyle & 30 & 28,$5 ; 29,5 ; 27,5$ & $26 ; 29 ; 29,5$ \\
\hline Length of odontophore & 30 & $28 ; 31,5 ; 28$ & $30 ; 28 ; 29,5$ \\
\hline Guiding ring from anterior end & 19 & 15,$5 ; 16,5 ; 17$ & 15,$5 ; 18,5 ; 18$ \\
\hline Length of amphid aperture & 9,5 & 8,$5 ; 8 \quad ; 9$ & $-\quad ; 8,5 ; 9,5$ \\
\hline Nerve ring from anterior end & 140 & $138 ; 145,5 ; 142$ & $131 ; 146,5 ; 148$ \\
\hline Length of oesophagus & 520 & $510 ; 565 ; 525$ & $515 ; 545 ; 560$ \\
\hline Body width & 59,5 & 60,$5 ; 56,5 ; 62,5$ & $55 ; 57 ; 60$ \\
\hline Distance from head to vulva & 300 & $261 ; 273 ; 291,5$ & $-\quad ;-;-$ \\
\hline Tail length & 220 & 163,$5 ; 232 ; 220$ & 174,$5 ; 162 ; 160,5$ \\
\hline Anal body diameter & 39 & 37,$5 ; 37 ; 37,5$ & 38,$5 ; 42,5 ; 43$ \\
\hline Length of rectum & 35,5 & $36 ; 34 ; 37$ & $-\quad ;-\quad ;-$ \\
\hline $\mathrm{OV}_{1} \%$ & 28,6 & $-\quad ; 60,1 ; 93,8$ & $-\quad ;-\quad ;-$ \\
\hline $\mathrm{OV}_{2} \%$ & 61,7 & $-\quad ; 63,6 ; 57,7$ & - ;- ;- \\
\hline Length of spicules & - & $-\quad ;-\quad ;-$ & 73,$5 ; 73,5 ; 72,5$ \\
\hline Length of lateral guiding pieces & - & $-;-\quad ;-$ & 16,$5 ; 21 ; 18$ \\
\hline $\begin{array}{l}\text { Number of ventromedian } \\
\text { supplements }\end{array}$ & - & - ; - ;- & $22 ; 20 ; 24$ \\
\hline Width of cuticle & 2,4 & 2,$5 ; 2,5 ; 2,5$ & $3 ; 3 ; 3$ \\
\hline Length of hyaline tail tip & 43,5 & $25 ; 35 ; 39,5$ & 32,$5 ; 51,5 ; 38$ \\
\hline
\end{tabular}

Specimens

Three females and three males, collected by A. Botha and W. Liebenberg in November, 1990, on slides W2797 and W2798.

Family Aporcelaimidae Heyns, 1965

Aporcelaimellus glandus n.sp. (Figs. 6A-K and 7A-F)

Morphometric data in Table 4.

Female

Small nematode, with relatively robust body. Heat-relaxed body posture slightly ventrally curved, slightly more curved posteriorly (Fig. $6 \mathrm{~K})$. Cuticle relatively thin: $2-3,5 \mu \mathrm{m}$ on the neck; $2,5-4 \mu \mathrm{m}$ at mid-body; $3,5-4,5 \mu \mathrm{m}$ on dorsal side of tail; and 1,5-4 $\mu \mathrm{m}$ at tail tip. Cuticle consisting of a thin outer layer, and

thick middle and inner layer of which only the two inner layers are shown in the figures. Exocuticle appears smooth, mesocuticle with distinct radial striae (appearing as faint punctations when seen en face), rather more prominent towards lip region and around tail (Figs. $6 \mathrm{~B} \& \mathrm{I}$ and $7 \mathrm{~A})$. Lateral chords one fifth to one fourth body diameter at base of oesophagus, appearing granular and with large gland cells at more or less regular intervals (Fig. 6E\&F). Lateral, dorsal and ventral body pores indistinct. Lateral body pores $29-43$, distributed over entire length of body (7-11 to base of oesophagus, 7-10 between oesophagus and vulva, and 15-22 between vulva and anus). The single row of lateral pores is irregularly spaced. Ventral body pores $31-38$, distributed over entire length of body (8-10 to base of oesophagus, 8- 10 between oesophagus and vulva and 15-18 between vulva and anus). Dorsal body pores about 3 , limited to anterior oesophageal region. 


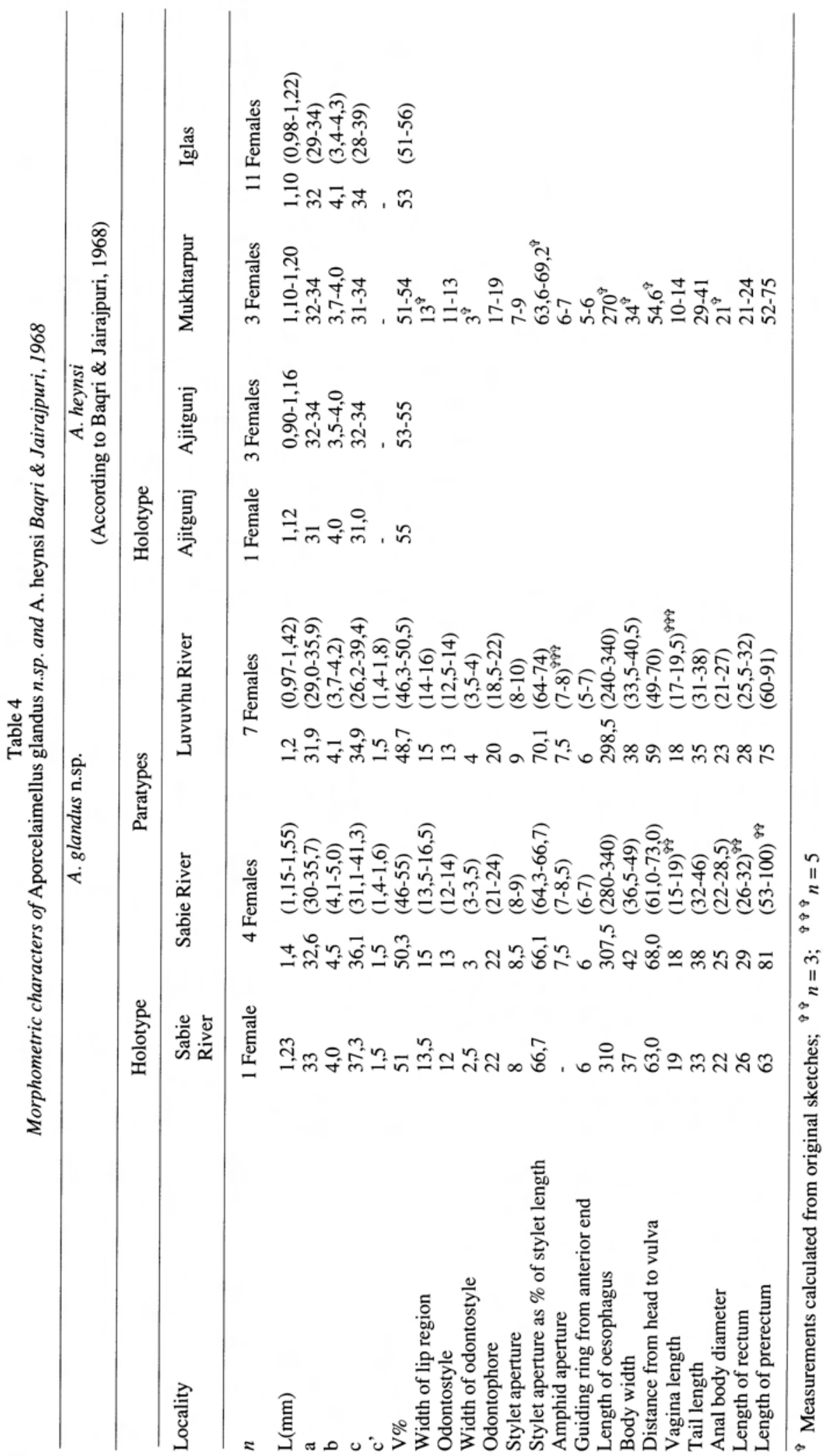




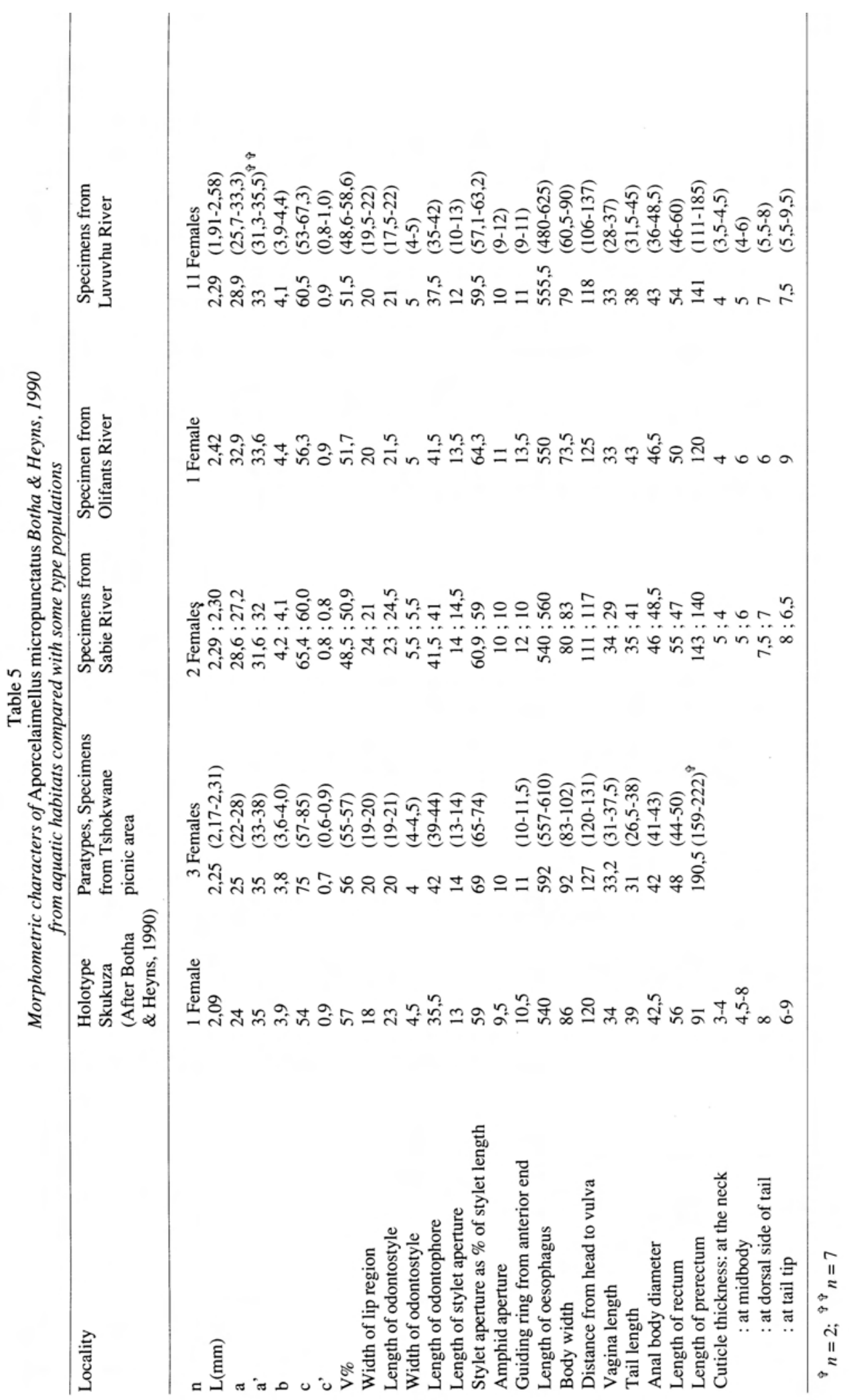


Table 6

Morphometric characters of Discolaimus monoplanus Heyns, 1963 and Discolaimus major Thorne, 1939 from aquatic habitats in the Kruger National Park

\begin{tabular}{|c|c|c|}
\hline & D. monoplanus & D. major \\
\hline$n$ & 1 Female & 2 Females \\
\hline $\mathrm{L}(\mathrm{mm})$ & 0,91 & 1,$61 ; 1,70$ \\
\hline a & 30,8 & 38,$3 ; 41$ \\
\hline b & 3,5 & 4,$0 ; 4,1$ \\
\hline $\mathrm{c}$ & 35 & 55,$5 ; 59,6$ \\
\hline c' & 1,3 & 1,$1 ; 1,1$ \\
\hline $\mathrm{V} \%$ & 45,6 & 49,$7 ; 47,1$ \\
\hline Width of lip region & 18,5 & $26 ; 25,5$ \\
\hline Length of odontostyle & 14,5 & $18 ; 19$ \\
\hline Width of odontostyle & 2,5 & $3 ; 3$ \\
\hline Length of odontophore & 23 & 35,$5 ; 34,5$ \\
\hline Length of stylet aperture & 9 & $10 ; 11$ \\
\hline Stylet aperture as \% of stylet length & 62,1 & 55,$6 ; 57,9$ \\
\hline Guiding ring from anterior end & 4,5 & $7 ; 8$ \\
\hline Amphid aperture & 5 & $8 ; 7$ \\
\hline Length of oesophagus & 260 & $400 ; 415$ \\
\hline Length of basal expanded part of oesophagus & 105 & $228 ; 241$ \\
\hline Width of basal expanded part of oesophagus & 15,5 & 20,$5 ; 22,5$ \\
\hline Distance from head to vulva & 415 & $800 ; 800$ \\
\hline Body width & 29,5 & $42 ; 41,5$ \\
\hline Tail length & 26 & $29 ; 28,5$ \\
\hline Anal body diameter & 20,5 & $26 ; 26,5$ \\
\hline Length of rectum & 18 & $32 ; 24,5$ \\
\hline Length of prerectum & 15 & $26 ; 10$ \\
\hline Cuticle width : on the neck & 2,5 & $4 ; 3$ \\
\hline : at mid-body & 3 & 3,$5 ; 2,5$ \\
\hline : at dorsal side of tail & 3 & $5 ; 4$ \\
\hline : around tail tip & 3 & $5 ; 5$ \\
\hline
\end{tabular}

Lip region distinctly set off by a constriction, about one third as wide as body at base of oesophagus. Lips rather angular in outline (Figs. 6A-C and 7A). Amphid stirrup-shaped (Fig. 6C), the aperture slightly more than half the lip region width, situated in the constriction. Amphid when viewed laterally appearing to be divided into two parts. Odontostyle rather distinct, its length slightly less or equal to lip region width. Aperture of odontostyle relatively large, slightly less than three quarters stylet length. Stylet width about one fifth to one fourth stylet length. Odontophore distinct, rod-like not expanded at its base and slightly less than twice lip region width. Guiding ring single, unsclerotized. Nerve ring distinct, situated at $85-114 \mu \mathrm{m}$ from anterior end. Anterior part of oesophagus which surrounds odontophore, not expanded.
Disc-shaped structure (Fig. 7B) present between oesophagus and cardia (Fig. 6A). Cardia hemispheriod, about as long as width of basal bulb of oesophagus. Oesophageal gland nuclei and their openings, seen in only one specimen, as follows $(n=1)$ : $\mathrm{DO}=57$; $\mathrm{DN}=60,9 ; \quad \mathrm{S}_{1} 0_{1}=67,4 ; \quad \mathrm{S}_{1} 0_{2}=75,1 ;$ $\mathrm{S}_{1} \mathrm{~N}_{2}=75,7 ; \quad \mathrm{S}_{2} 0_{1}=85,7 ; \quad \mathrm{S}_{2} \mathrm{~N}_{1}=84,3$; $\mathrm{S}_{2} \mathrm{O}_{2}=86,1 ; \mathrm{S}_{2} \mathrm{~N}_{2}=84,7$. $\mathrm{S}_{1} \mathrm{~N}_{1}$ obscure.

Intestinal cells large, packed with brownish granules; intestine six cells in circumference. Junction between intestine and prerectum distinct. Sphincter at junction of prerectum and rectum obscure. Prerectum length about 2,4-3,6 times anal body diameter. Rectum length about 0,9-1,3 times anal body diameter. Tail dorsally convex-conoid, terminus rounded (Figs. 6I \& J and 7E\&F). 


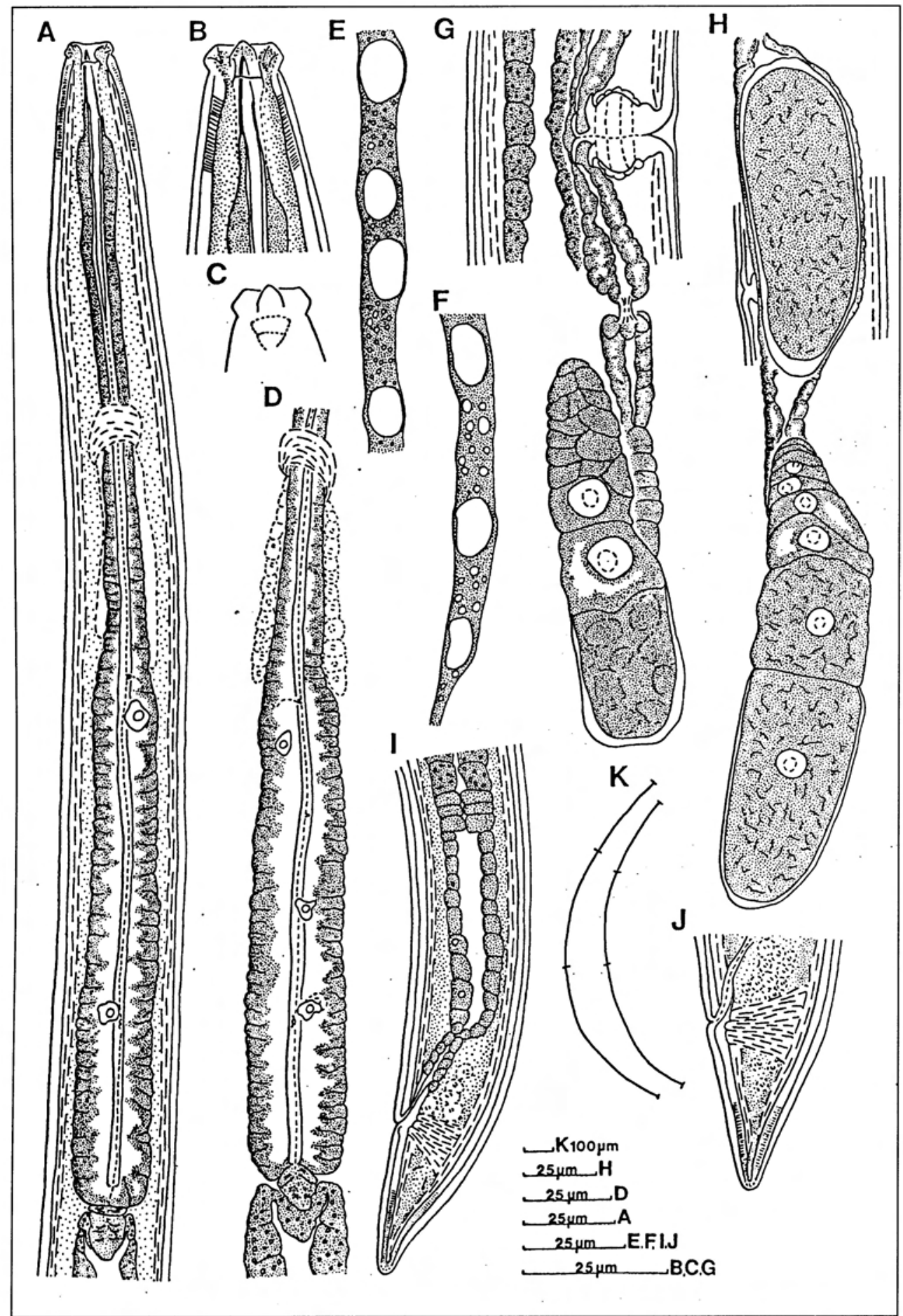

Fig. 6. Aporcelaimellus glandus n.sp.: A. Anterior body region of female; B. Lateral view of female head; C. Shape and position of amphid; D. Lateral view of oesophagus of female; E. and F. Lateral chord at base of oesophagus and in tail region; G. and H. Posterior branch of reproductive system of female; I. Posterior body region of female; J. Female tail; K. Heat-relaxed body posture of two females. 

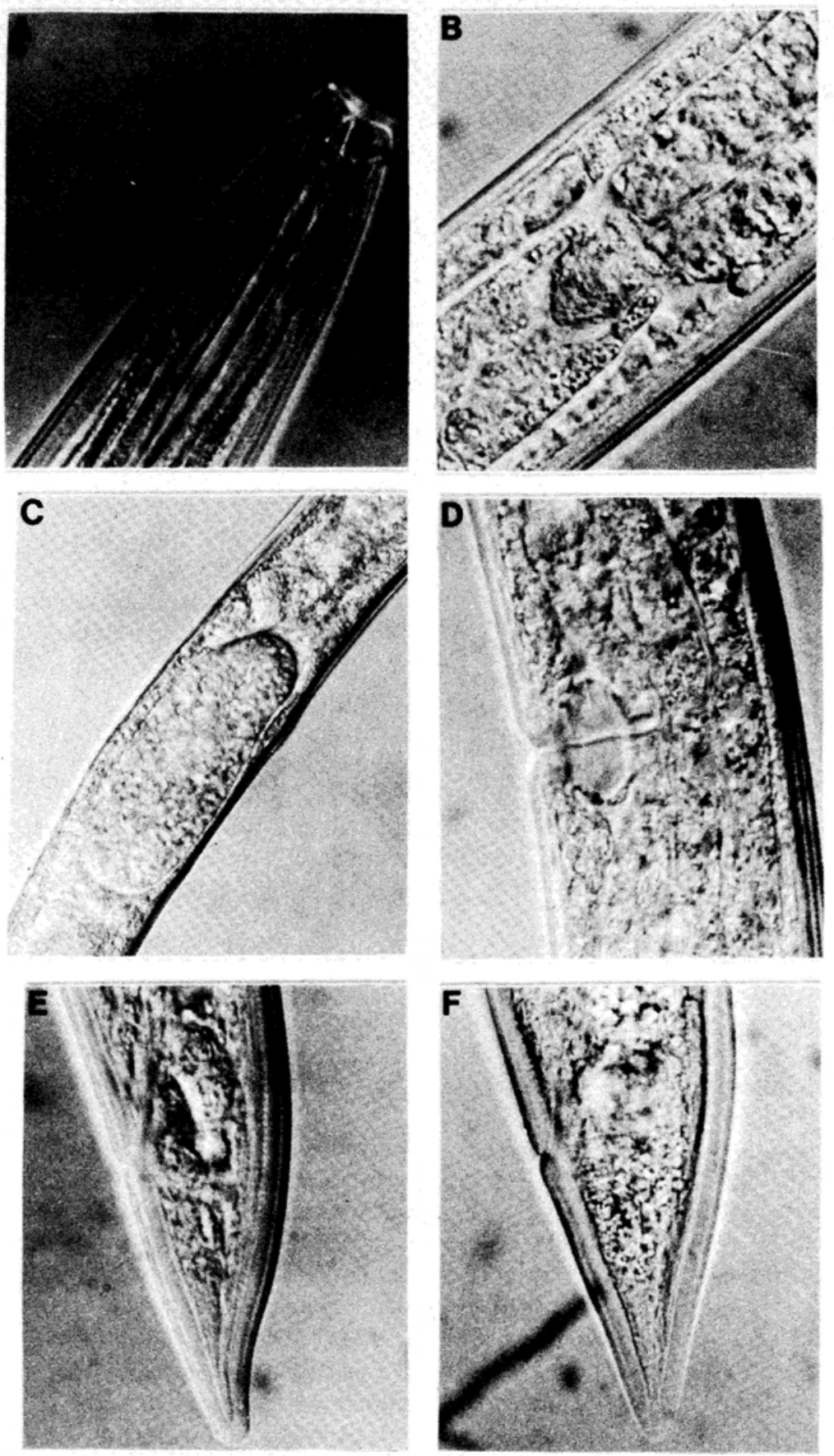

A-F

Fig. 7. Aporcelaimellus glandus n.sp.: A. Lateral view of head; (bar equals $10 \mu \mathrm{m}$ ); B. Cardiac region (bar equals $8,5 \mu \mathrm{m}$ ); C. Egg in female reproductive system (bar equals $23 \mu \mathrm{m}$ ); D. Vaginal region (bar equals 8,5 $\mu \mathrm{m}$ ); E. and F. Variation in tail shape (bar equals $8,0 \mu \mathrm{m}$ and $9,5 \mu \mathrm{m}$ respectively). 
Two pairs of caudal pores present, one pair subdorsal and one pair subventral.

Female didelphic, amphidelphic (Fig. $6 \mathrm{G} \& \mathrm{H})$. Ovaries reflexed dorsally. Ovaries and oviduct very prominent; pars dilatata oviductus less prominent. Distinct sphincter between oviduct and uterus. Pars dilatata uteri not clearly differentiated. Vagina strongly muscular (Fig. 7D), reaching 40,5$52 \%$ of the corresponding body diameter. Vulva a transverse slit, without sclerotized lips. No sperm cells observed in uterus. Two females with one uterine egg each, measuring $100 \times 35 \mu \mathrm{m}$ and $98 \times 37 \mu \mathrm{m}(n=2)$.

\section{Male unknown}

\section{Diagnosis}

Aporcelaimellus glandus n.sp. is a small nematode with large gland cells in the lateral chords; a distinctly set-off lip region with rather angular lips and a disc-shaped structure between base of oesophagus and cardia; tail dorsally convex-conoid with rounded terminus and the vulva a transverse slit without sclerotized labia.

\section{Differential diagnosis}

Aporcelaimellus glandus n.sp. is very similar to the Indian species, A. heynsi Baqri \& Jairajpuri, 1968 except for a somewhat longer body $(\mathrm{L}=0,97-1,55 \mathrm{~mm}$ compared with $\mathrm{L}=0,90-1,22 \mathrm{~mm}) ;$ a relatively shorter oesophagus $(b=3,7-5,0$ compared with $b=3,4$ $4,3)$; slightly longer tail (31-46 $\mu \mathrm{m}$ compared with $29-41 \mu \mathrm{m}$ ); a slightly more anteriorly situated vulva (V=46- $55 \%$ compared with $\mathrm{V}=51-56 \%)$; a longer odontophore (18,5-24 $\mu \mathrm{m}$ compared with 17$19 \mu \mathrm{m})$; a more posteriorly situated nerve ring (85-114 $\mu \mathrm{m}$ from anterior end compared with $86-95 \mu \mathrm{m}$ from anterior end); a longer vagina $(15-19 \mu \mathrm{m}$ compared with $10-14 \mu \mathrm{m})$; a longer rectum (26-32 $\mu \mathrm{m}$ compared with 21-24 $\mu \mathrm{m}$ ); a slightly longer prerectum (53$100 \mu \mathrm{m}$ compared with $52-75 \mu \mathrm{m}$ ). The amphid of $A$. glandus n.sp. is stirrup-shaped and horizontally divided into two parts whereas in A. heynsi, it is cup-shaped and undivided. The lateral chords of $A$. glandus n.sp. have large gland cells whereas in $A$. heynsi it is granular.

\section{Type locality and habitat}

Holotype and four paratypes from three different localities in the Sabie River: in sand from the river bank between Nkuhlu picnic area and Lower Sabie Camp; in sand under Phragmites at the weir east of Lower Sabie Camp and in the river sediment, just east of Nwatindlopfu Spruit; collected by A. Botha and J. Heyns in February, 1990. Seven paratypes from two different localities in the Luvuvhu River: in mud from the river bank near the picnic area north-west of Pafuri and in damp sand from the river bank near the junction of the Luvuvhu and Limpopo rivers; collected by J. Heyns in February, 1991.

\section{Type specimens}

Holotype on slide W2592, paratypes from Sabie River on slides W2560, W2572, W2592 and W2618; and paratypes from Luvuvhu River on slides W2822, W2830, W2831, W2871-W2873 and W2878.

Aporcelaimellus micropunctatus Botha \& Heyns, 1990 (Figs. 8A-I and 9A-F) Morphometric data in Table 5

The original description (Botha \& Heyns 1990a) of Aporcelaimellus micropunctatus was based on specimens collected from soil around the roots of grasses in several localities in the central part of the Kruger National Park. Fourteen further specimens of this species have now been found, in aquatic habitats, viz. the Sabie, Olifants and Luvuvhu rivers.

Comparison with the types showed that the present specimens are similar to the population from the Tshokwane picnic area. They differ slightly from the specimens from the Skukuza Camp, the vicinity of the Engelhard Dam and the Letaba area by a slightly longer body $(\mathrm{L}=1,91-2,58 \mathrm{~mm}$ compared with $\mathrm{L}=1,72-2,11 \mathrm{~mm})$; slightly wider lips (19,5$24 \mu \mathrm{m}$ compared with $17,5-20 \mu \mathrm{m}) ; \quad$ a 


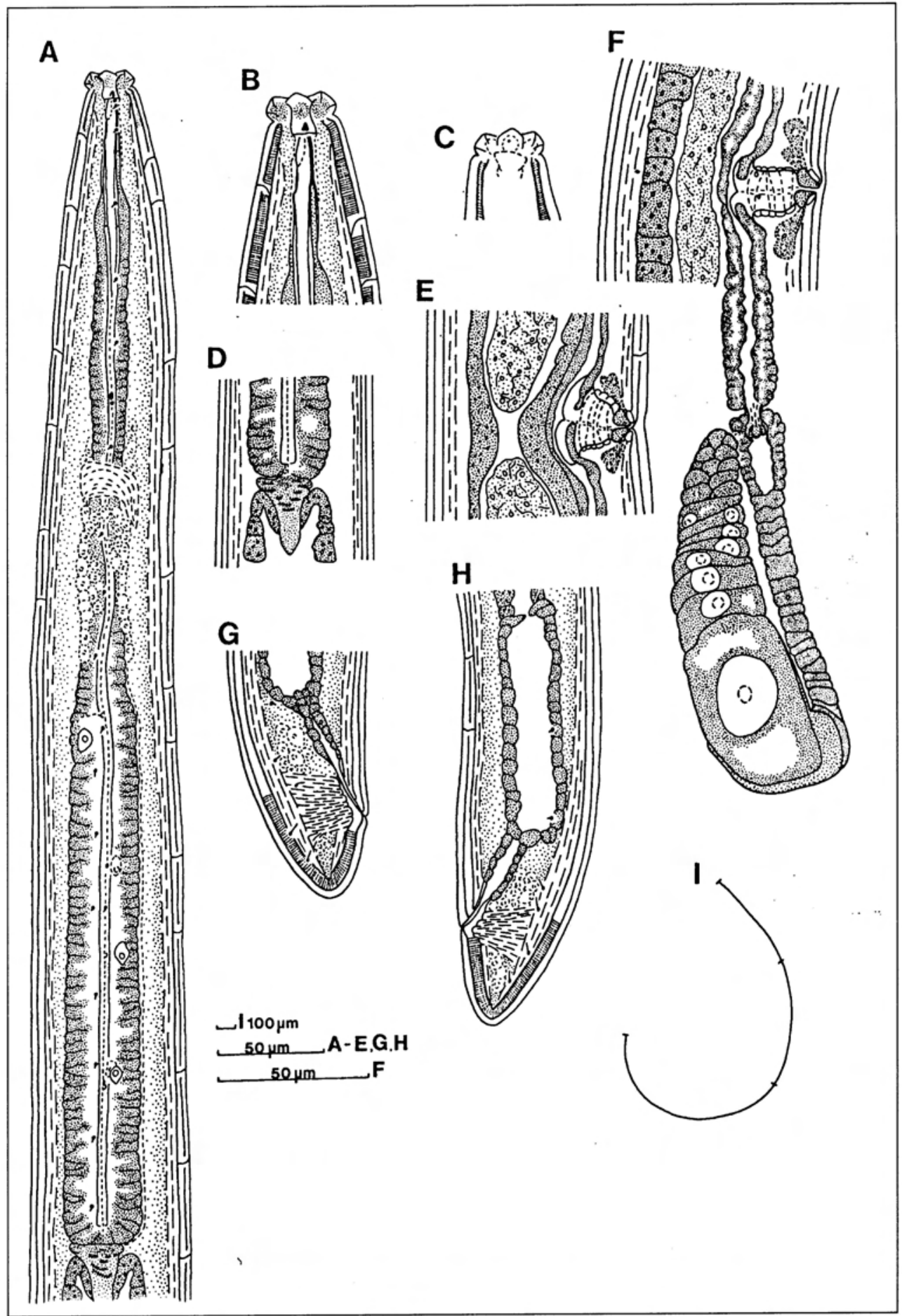

Fig. 8. Aporcelaimellusmicropunctatus Botha \& Heyns, 1990: A. Anterior body region of female; B. Lateral view of head; C. Shape and position of amphid; D. Cardiac region; E. Vaginal region; F. Posterior branch of reproductive system of female; G. Female tail; H. Posterior body region of female; I. Heat-relaxed body posture of female. 

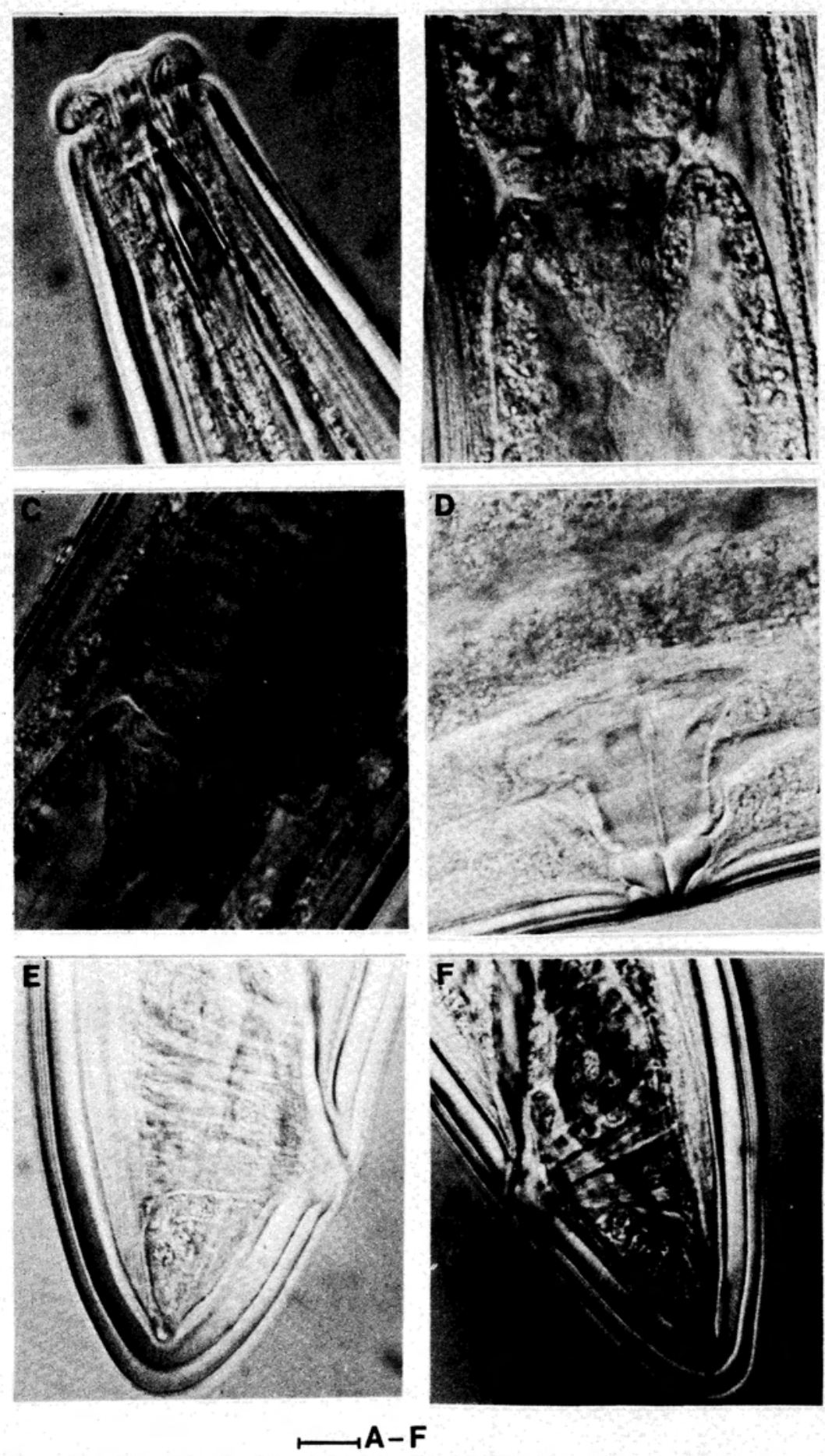

Fig. 9. Aporcelaimellusmicropunctatus Botha \& Heyns, 1990: A. Lateral view of head (bar equals 8,5 $\mu \mathrm{m}$ ); B. and C. Cardiac region (bar equals $8,5 \mu \mathrm{m}$ and $10 \mu \mathrm{m}$ respectively); D. Vaginal region (bar equals $10,5 \mu \mathrm{m}$ ); E. and F. Variation in tail shape (bar equals $9 \mu \mathrm{m}$ and $10 \mu \mathrm{m}$ respectively). 
slightly greater anal body diameter (36$48,5 \mu \mathrm{m}$ compared with $35-45,5 \mu \mathrm{m}$ ) and a slightly more anteriorly situated vulva $(\mathrm{V}=48,5-58,6 \%$ compared with $\mathrm{V}=51-59 \%)$. From the specimens of the Tshokwane picnic area, they differ only by a slightly longer body $(\mathrm{L}=1,91-2,58 \mathrm{~mm}$ compared with $\mathrm{L}=2,09-2,31 \mathrm{~mm}$ ); a slightly wider lip region (19,5-24 $\mu \mathrm{m}$ compared with $19-20 \mu \mathrm{m})$; a slightly longer odontostyle (17,5-24,5 $\mu \mathrm{m}$ compared with 19-21 $\mu \mathrm{m}$ ) and a slightly longer tail (31,5-45 $\mu \mathrm{m}$ compared with $26,5-$ $38 \mu \mathrm{m})$.
New distribution data

Two specimens collected from two different localities in the Sabie River, namely in wet sand from the river bank between the Nkuhlu picnic area and Lower Sabie Camp and in the sand between Phragmites at the weir east of Lower Sabie Camp, collected by A. Botha and J. Heyns in February, 1990. One specimen from one locality in the Olifants River, namely in the sediment of the river west of the weir, collected by J. van Vuren in June, 1990. Eleven specimens from three localities
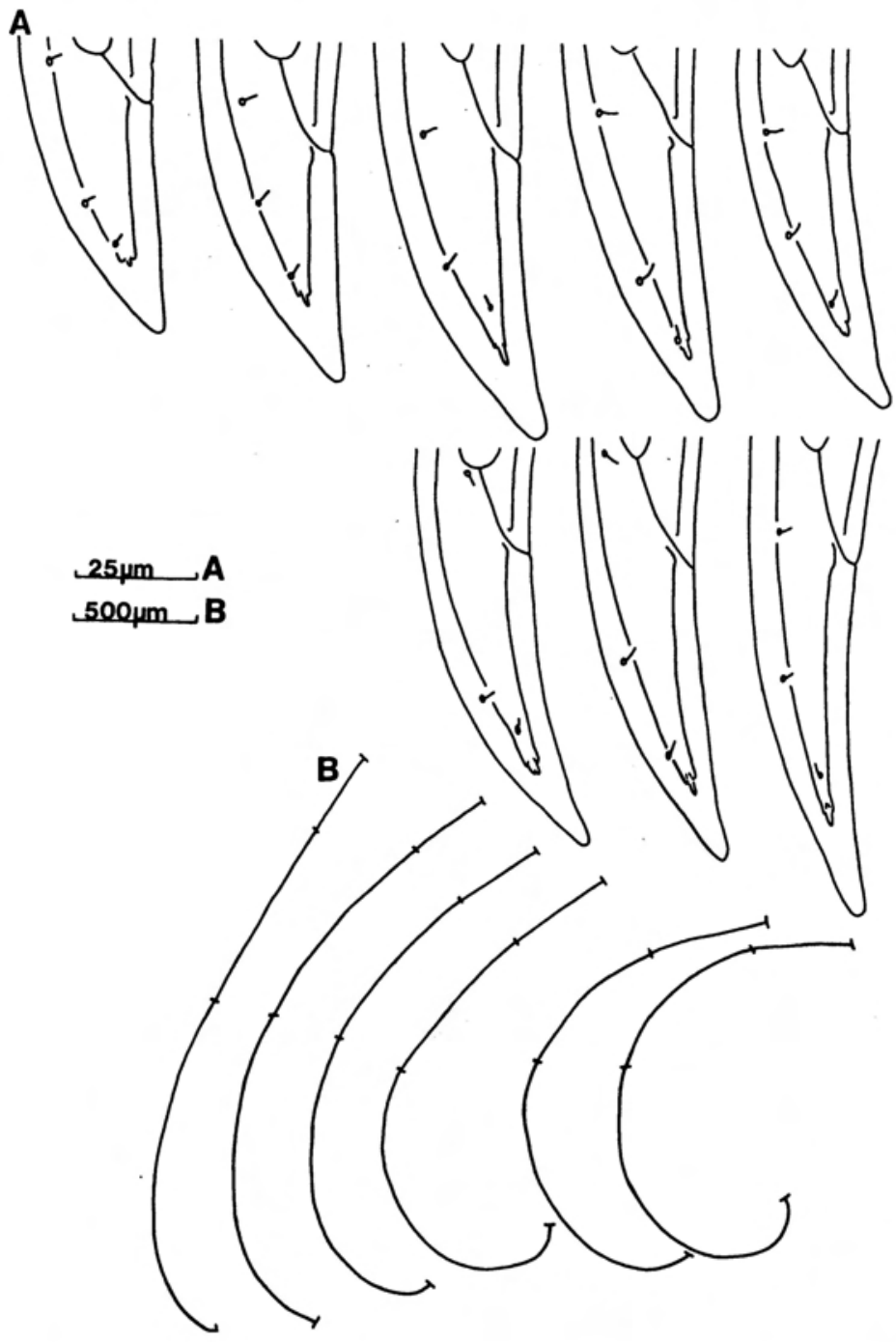

Fig. 10. Xiphinema italiae Meyl, 1953: A. Variation in tail shape; B. Variation in heat-relaxed body posture. 
in the Luvuvhu River namely: in mud from the river bank near the picnic area north-west of Pafuri; in a shallow stagnant pool west of Pafuri and from the river bank near the confluence of the Luvuvhu and Limpopo rivers, collected by J. Heyns in February, 1991.

\section{Specimens}

Two specimens from Sabie River on slides W2576 and W2603, one specimen from Olifants River on slide W2689 and eleven specimens from Luvuvhu River on slides W2821, W2823, W2824, W2834, W2843, W2856, W2877 and W2879.

Family: Discolaimidae Siddiqi, 1969

\section{Discolaimus monoplanus Heyns, 1963}

Morphometric data in Table 6.

The description of Discolaimus monoplanus Heyns, 1963, was based on a single female from Rustenburg, Transvaal, South Africa. Botha \& Heyns (1990b) have since reported a single female from Skukuza in the Kruger National Park and a now further female has been found in the sand from the bank of the Luvuvhu River at the confluence of the Luvuvhu and Limpopo rivers. This specimens is similar to the holotype and the specimen from Skukuza, except for a slightly longer body $(\mathrm{L}=0,91 \mathrm{~mm}$ compared with $\mathrm{L}=0,79 \mathrm{~mm}$ of the holotype and $\mathrm{L}=0,84 \mathrm{~mm}$ of the specimen from Skukuza).

\section{Specimens}

A single female collected by $\mathrm{J}$ Heyns in February, 1991 from the Luvuvhu River, on slide W2874.

\section{Discolaimus major Thorne, 1939}

Morphometric data in Table 6.

Discolaimus major was first reported from the Kruger National Park by Van der Vegte \& Heyns (1963). Three further specimens were reported from the Letaba area and the Skukuza Camp by Botha \& Heyns (1990b).
The two present specimens, collected by Heyns in February, 1991 have been found in sand from the river bank at the confluence of the Luvuvhu and Limpopo rivers. They differ slightly from the specimens from Skukuza Camp and Letaba area by a shorter body length $(\mathrm{L}=1,61-1,70 \mathrm{~mm}$ compared with $\mathrm{L}=1,93-2,20 \mathrm{~mm}$ ).

\section{Specimens}

Specimens on slides W2872 and W2875

Family: Longidoridae Thorne, 1935

Xiphinema italiae Meyl, 1953 (Fig. 10A\&B)

Morphometric data in Table 7.

The original description of Xiphinema italiae Meyl, 1953 was based on specimens collected from the island Ischia, Italy. Heyns (1974) reported it for the first time from the Kruger National Park among grasses at the Tshokwane picnic area and near the hippo pool west of the Skukuza Camp. In the same paper he also reported it from several other localities in the Transvaal and from the northern part of Natal; Van Reenen \& Heyns (1986) reported specimens of $X$. italiae from the Berg River area in the Cape Province. The present specimens of $X$. italiae from the Sabie and Luvuvhu rivers in the Kruger National Park differ slightly from the specimens reported by Heyns (1974) in having a more ventrally curved heat-relaxed body posture and a slightly longer odontostyle (82-109,5 um compared with $80-91 \mu \mathrm{m})$. The specimens from the Sabie River further differ in having a slightly shorter tail $(47-57 \mu \mathrm{m}$ compared with 52-67 $\mu \mathrm{m}$ ) and a smaller c'- ratio (1,9-2,2 compared with $2,3-2,8)$; the specimens from the Luvuvhu River differ in having a slightly longer tail (54-74 $\mu \mathrm{m}$ compared with 52-67 $\mu \mathrm{m})$ and a greater c'-ratio (2,3-3,4 compared with 2,3-2,8). Finally, the present specimens differ from those reported by Van Reenen \& Heyns (1986) in having a slightly shorter body $(\mathrm{L}=2,38-2,69 \mathrm{~mm}$ compared with $\mathrm{L}=2,23-3,11 \mathrm{~mm}$ ) and a slightly shorter tail (47-74 $\mu \mathrm{m}$ compared with $52-81 \mu \mathrm{m})$. 


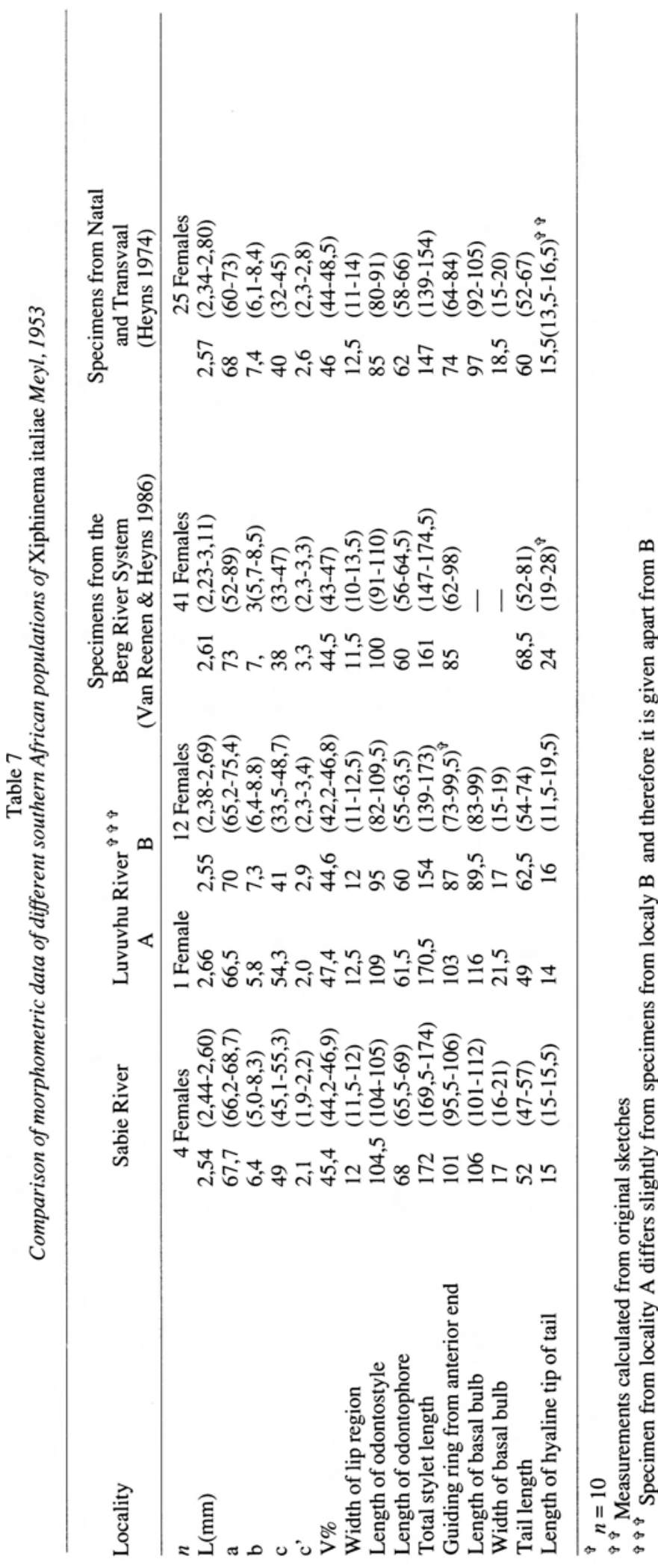


Locality and habitats

Four specimens collected from the Sabie River in sand among the roots of Phragmites near the weir east of the Lower Sabie Camp. One specimen collected from mud in the Luvuvhu River, near the picnic area northwest of Pafuri. Thirteen specimens collected in sand from the river bank of the confluence the Luvuvhu and Limpopo rivers.

\section{Specimens}

Specimens from the Sabie River on slides W2580, W2583, W2586 and W2599; specimens from the Luvuvhu River on slides W2824, W2866-W2869.

\section{Acknowledgements}

We thank the National Parks Board for permission to collect in the Kruger National Park, and Dr. Andrew Deacon after whom one of the species is named, for his logistical assistance. The Foundation for Research Development is thanked for financial support.

\section{References}

ALTHERR, E. and CL. DELAMARE-DEBOUTTEVILLE. 1972. Nématodes interstitiels des eaux douces des États-Unis d'Amérique (États de Washington, du Colorado et du Massachusetts) récoltés par $\mathrm{Cl}$. Delamare-Debouttville. Annales de Speteologie 27(4): 721-725.

ANDRÁSSY, I. 1960. Einige Nematoden aus Afghanistan. Opuscula Zoologica Budapest 4(1): 3-14.

ANDRÁSSY, I. 1970. Nematoden aus einigen flusssystemen Südafrikas. Opuscula Zoologica, Budapest. 10(2): 179-219.

BAQRI, Q.H. and M.S. JAIRAJPURI. 1968. On six new species of Dorylaimida (Nematoda).Journal of Helminthology 42(3/4): 243-256.
BOTHA, ANNELIZE and J. HEYNS. 1990a. Aporcelaimidae (Nematoda: Dorylaimida) from the Kruger National Park. Koedoe 33(2): 27-46.

BOTHA, ANNELIZE and J. HEYNS. 1990b. Dorylaimoidea (Nematoda) from the Kruger National Park. Koedoe 33(2): 47-59.

COBB, N.A. 1914. North American free-living freshwater nematodes. Transactions of the American Microscopical Society 33(2): 69-134.

HEYNS, J. 1963. A report on South African nematodes of the genera Labronema Thorne, Discolaimus Cobb, Discolaimoides n.gen. and Discolaimium Thorne (Nematoda: Dorylaimoidea). Proceedings of the Helminthological Society of Washington 30(1): 1-6.

HEYNS, J. 1974. The genus Xiphinema in South Africa II. X. elongatum- group (Nematoda: Dorylaimidae). Phytophylactica 6(3): 249-260.

LOOF, P.A.A. 1969. Taxonomy of some species of the genus Mesodorylaimus Andrássy, 1959 (Dorylaimoidea). Nematologica 15: 253-274.

MEYL, A.H. 1953. Beiträge zur Kenntnis der Nematoden fauna vulkanisch erhitzter Biotope. I. Mitt., Die Terrikolen Nematoden in Bereich von Fumarolen auf der Insel Ischia. Zeitschrift für Morphologie und Ökologie der Tiere. 42(1): 67116.

SWART, ANTOINETTE and J. HEYNS. 1991. Lenonchium fimbricaudatum n.sp. from South Africa, with a key to the species of Lenonchium (Nematoda: Nordiidae). Revue de Nématologie. 14(3): 413-418.

STEINER, G. 1919. Die von A. Monard gesammelten Nematoden der Tiefenfauna des Neuenburgersees. Bulletin de la Societe neuchâteloise des sciences naturelles. 43: 142-240.

THORNE, G.E. and H.H. SWANGER. 1936. A monograph of the genera Dorylaimus Dujardin, Aporcelaimus n.g., Dorylaimoides n.g., and Pungentus n.g. Capita Zoologica. 6(4): 1-223.

VAN DER VEGTE, F.A. and J. HEYNS. 1963. A report on nematodes found in soil and root samples from the Kruger National Park. Koedoe 6: 134- 136.

VAN REENEN, ERINA and J. HEYNS. 1986. A survey of Longidoridae in vineyards along the Berg River System. Phytophylactica 18(4): 203207. 